\title{
KURUMSAL SOSYAL SORUMLULUK ÇALIŞMALARI BENZER TEMALAR ÜZERİNE Mİ YOĞUNLAŞMAKTADIR? BİST 100 ŞİRKETLERİ ÜZERİNE BİR ARAŞTIRMA1
}

\author{
Nadide MACİT
}

Karamanoğlu Mehmetbey Üniversitesi, SBE, İşletme ABD, Yüksek Lisans ORCID: 0000-0002-8225-0163

Oğuzhan AYTAR

Doç. Dr., Karamanoğlu Mehmetbey Üniversitesi, İIBF, İşletme Bölümü ORCID: 0000-0003-3799-0952

\begin{abstract}
Öz
21. yüzyılın ilk çeyreğinde işletmelerin başarısı, sadece finansal kriterlerle değil, işletme paydaşlarının beklentilerini ne düzeyde karşıladıklarıyla da ölçülmektedir. $\mathrm{Bu}$ beklentilerin önemli bölümünün kurumsal sosyal sorumluluk faaliyetleriyle karşılandığı bilinmektedir. Bu çalışmanın amacı, BIST 100 Endeksinde yer alan şirketlerin kurumsal sosyal sorumluluk çalışmalarına yönelik karşılaştırmalı bir içerik analizinin yapılarak elde edilen anlamlı sonuçların paylaşılmasıdır. Bu kapsamda BIST 100 Endeksinde yer alan şirketlerin kurumsal sosyal sorumluluk uygulamaları değerlendirilmiştir. Çalışmada nitel araştırma yöntemlerinden içerik analizi kullanılmıştır. Çalışma sonucunda BİST 100, BIST 50 ve BİST 30 şirketlerinin yoğunlaştıkları kurumsal sosyal sorumluluk faaliyetleri arasında fark bulunmadığı, sektör grupları açısından bir karşılaştırma yapıldığında kurumsal sosyal sorumluluk temaları arasında anlamlı farklılıkların bulunduğu tespit edilmiştir.
\end{abstract}

Anahtar Kelimeler: Kurumsal Sosyal Sorumluluk, BİST 100, İçerik Analizi.

\section{ARE CORPORATE SOCIAL RESPONSIBILITY STUDIES CONCENTRATED ON SIMILAR THEME? A RESEARCH ON BIST 100 COMPANIES}

\begin{abstract}
Business success in the first quarter of the 21st century is evaluated not only by financial criteria, but also by the degree to which they fulfil the aspirations of business stakeholders. It is known that most of these expectations are met by corporate social responsibility activities. The purpose of this study is to share the meaningful results obtained by making a comparative content analysis for the corporate social responsibility studies of

\footnotetext{
1 Bu makale, Nadide Macit'in Karamanoğlu Mehmetbey Üniversitesi, SBE, İșletme ABD' nda Oğuzhan Aytar danışmanlığında savunduğu "BİST şirketlerinin kurumsal sosyal içerik analizi" isimli yüksek lisans tez çalışmasından üretilmiştir.
} sorumluluk faaliyetleri: BİST 30, BIST 50, BIST 100 endeksleri üzerine karşılaştırmalı bir
\end{abstract}


the companies included in the BIST 100 Index. In this context, the corporate social responsibility activities of companies included in the BIST 100 Index were evaluated. Content analysis was used in this study one of the qualitative research methods. In the results of study there is no difference between the activities of corporate social responsibility concentrated on by BIST 100, BISST 50 and BIST 30 companies, when a comparison is made in terms of sector groups, it has been determined that there are significant differences between corporate social responsibility themes.

Keywords: Corporate Social Responsibility, BİST 100, Content Analysis.

\section{GİRIş}

İşletmelerin büyümeleri ve yaşamlarını sürdürebilmeleri, değişen ve gelişen çevresel gelişmelere uyum yetenekleriyle ilişkilidir. Günümüzde kurumsal sosyal sorumluluk (KSS) kavramı ve faaliyet türleri işletmelerin varlıklarını sürdürülebilir hale getirmeleri açısından stratejik bir öneme sahiptir. Küreselleşen dünyayla birlikte toplumsal sorunların artması ve toplumun çevresel gelişmelere yönelik artan endişesi, şirketler açısından kurumsal sosyal sorumluluk (KSS) kavramının farklı açılardan değerlendirilmesini gerekli kılmıştır. Paydaşların işletmeler üzerindeki baskısı kurumsal sosyal sorumluluğun iş dünyasında fonksiyonel bir boyut kazanmasına neden olmaktadır (Ben-Amar, Francoeur, Marsat ve Sijamic Wahid, 2021:3). İşletmeler kurumsal sosyal sorumluluk faaliyetlerini halkla ilişkiler yönetimi, itibar yönetimi ve çevre yönetimi çerçevesinde kurumsallaştırarak iş süreçlerine entegre etmeye çalışmaktadırlar.

Günümüz işletmelerinin başarısı; yalnızca girdileri mal ve hizmetlere dönüştürme becerisiyle değil, aynı zamanda sosyal ve çevresel sorunların çözümüne kattlımıyla belirlenmektedir. Kurumsal sosyal sorumluluk kavramı, çevresel etkilerin azaltılması, atık yönetiminin iyileştirilmesi, çevresel düzenlemelere uyum, çalışanların korunması gibi toplumla ilgili kurumsal faaliyetleri içermektedir (Miniaoui, Chibani ve Hussainey, 2019:1). Kalite, hizmet, yarar ve fiyat gibi geleneksel faktörlerin yanı sıra stratejik niyet, çalışan davranışları, toplumsal bilinç ve çevresel duyarlılık gibi konular, kurumsal sosyal sorumluluğun işletme başarısında önemli bir etkisi olduğunu göstermektedir. İşletmeler uyguladıkları kurumsal sosyal sorumluluk çalışmaları ile çevrelerindeki sorunlara (doğal kaynakların korunması, çevre kirliliğinin önlenmesi, kıtlık, eğitim, sağlık vb.) cevap vererek topluma katkı sunmaktadırlar. Topluma yönelik gerçekleștirilen bu katkılar, işletmeye rekabet ortamında büyük avantajlar kazandırmaktadır. İşletmenin toplum nezdinde itibarının artması, piyasadaki değer ve konumunun güçlenmesi, tedarikçi, müşteri ve toplumla arasındaki olumlu etkileşimin artması bunlardan bazılarıdır (Korkmaz, 2009:17; Çalışkan, 2010:26; Özkan, Tanç ve Taşdemir, 2018:572; Awalluddin, 2020:3). İşletmelerin faaliyetlerine kurumsal sosyal sorumluluk faaliyetlerini entegre ederek yürütmeleri işletme sürekliliği ve kârlılığı için büyük bir öneme sahiptir (Kelgökmen İlic, 2010:304).

\section{ALANYAZIN TARAMASI}

Kurumsal sosyal sorumluluk faaliyetlerinin işletme grupları ve türlerine göre nasıl farklılaştığı veya uyum gösterdiğine dair sınırlı sayıda 
çalışma bulunmaktadır. Yapılan araştırmaya paralel olarak işletme grupları ve Kurumsal Sosyal Sorumluluk (KSS) faaliyetleriyle doğrudan ilişkili olan çalışmalar şunlardır:

Yıldırım (2013) çalışmasında, 2011 ve 2012 dönemleri içinde BİST 30 endeksi içinde bulunan altı (6) şirketin kurumsal yönetim ilkeleri uyum raporları ve finansal tablolarını kurumsal sosyal sorumluluk açısından incelemiştir. Çalışma kapsamında elde edilen veriler oran analizi ve içerik analiziyle incelenmiştir. Araştırma sonucunda, toplumun KSS açıklamalarına genel olarak duyarlı oldukları tespit edilmiștir. Bununla birlikte 2011 yılı uyum raporu sonuçlarında en çok personel, arz edilen ürün, tüketici, toplum ve çevre konularına değinildiği, 2012 yılı sonuçlarının ise 2011 yılı sonuçlarıyla benzerlik taşıdığı tespit edilmiştir.

Pusak (2014) çalışmasında İSO 500'e giren 2012 yılının en büyük 200 şirketinin internet ortamında taranması ile 14 şirketten elde edilen 14 adet Kurumsal Sosyal Sorumluluk (KSS) veya sürdürülebilirlik başlıklı raporları içerik analizi yöntemiyle incelemiştir. Şirketlerin raporlarında çevre, sağlık, güvenlik, eğitim, kültür, sanat, spor ve paydaşlarla ilgili seçilen alt kategorilere birbirinden çok farklı düzeylerde yer verdikleri görülmüştür. Her kategorinin şirketler arasındaki düzeyinin birbirinden çok farklı olduğu, dolayısıyla her şirketin aynı KSS uygulamasını birbirinden çok farklı düzeyde gerçekleştirdiği gözlemlenmiştir.

Tarcan, İçigen, Çevik ve Doğan (2016), Türkiye içinde hizmet sunan 28 uluslararası zincir otelin kurumsal web sitelerinde ve sosyal medya platformlarında yer alan sosyal sorumluluk faaliyetlerini incelemiştir. Çalışmada içerik analizi yöntemi kullanılmıştır. İnceleme kapsamında değerlendirilen işletmelerin sosyal sorumluluk en fazla yoğunlaştıkları çalışmaların çevre, afet, yoksulluk, eğitim, yerel konular ve sağlık konuları olduğu tespit edilmiştir. İşletmelerin en az uyguladıkları sosyal sorumluluk faaliyetlerinin ise kültürel çalışmalar olduğu gözlemlenmiştir.

De Jong ve Van Der Meer (2017), yaptıkları çalıșmada, KSS faaliyetleri ile şirketlerin faaliyet alanları arasındaki uyumu araştırmışlardır. Hollanda hükümetinin 2011 yılında yayınladığı şeffaflık raporunda yer alan şirketler araştırmaya dâhil edilmiştir. Şirketlerin 2011 yılındaki yıllık raporları ve KSS raporları içerik analiziyle incelenmiştir. Çalışma sonucunda, şirketler ve KSS faaliyetleri arasında uyumun olduğu tespit edilmiştir.

Demirel (2018), çalışmasında, Türkiye'nin en büyük 500 sanayi kuruluşu arasından büyüklük sırasına göre seçtiği 200 şirketin kurumsal internet sitelerinin taranmasıyla 29 adet sosyal sorumluluk raporunu içerik analizi yöntemiyle incelemiştir. Türkiye'de az sayıda işletmenin KSS raporu yayınladığı tespit edilmiştir. İşletmelerin KSS raporlarında kültür, sanat, spor konusundaki uygulamalara daha az yer verdikleri ve çevre ile ilgili konulara ise daha çok yer verdikleri görülmüştür.

Soysal (2019), çalışmasında, 2017 yılına ait verilerden yola çıkarak İSo 500 listesindeki şirketler arasından, toplam satış miktarı İSO 500'ün yaklaşık 
onda sekizine denk gelen ilk 250 şirketi seçerek bu şirketlerin KSS faaliyetlerini içeren sürdürülebilirlik raporlarını incelemiștir. Raporlar içerik analizi ve tanımlayıcı istatiksel çözümleme yöntemleriyle incelenmiştir. Şirketlerin KSS raporlarında, kategorilere birbirlerinden farklı düzeyde yer verdikleri görülmüştür. Kimi şirketlerin, çevre konusuna daha fazla önem verdikleri görülürken, kimi şirketlerinde çevresel faaliyetler sınıfı altındaki temiz enerji, atık ve emisyon gibi konulara daha fazla önem verdikleri tespit edilmiștir. Yine bazı şirketler, sağlık ve güvenlik konularına önem verirken, bazı şirketlerin de eğitim, kültür, sanat gibi konulara daha fazla önem verdikleri tespit edilmiştir.

Aytar (2019), yaptı̆̆ı çalıșmasında BİST Sürdürülebilirlik Endeksinde yer alan işletmelerin kurumsal sosyal sorumluluk çalışmalarını içerik analizi yöntemiyle incelemiştir. BİST Sürdürülebilirlik Endeksi içindeki işletmelerin KSS faaliyetlerinde hangi konulara daha fazla ağırlık verdikleri, bu çalışmaların ne yönde gelişim gösterdiği ve KSS faaliyetlerinin endeks içinde sektörel açıdan farklılık taşıyıp taşımadığını belirlemeye çalıșmıștır. Yapılan çalışmada, Sürdürülebilirlik Endeksi içinde bulunan şirketlerin KSS çalışmalarının işletme ve sektör grupları açısından farklılıklar taşıdığı tespit edilmiştir. BİST Sürdürülebilirlik Endeksinde yer alan şirketlerin KSS çalışmaları kapsamında ağırlıklı olarak sosyal ve kültürel faaliyetler kategorisindeki çalışmalara yer verdikleri gözlemlenmiștir.

Süklüm ve Hiçyorulmaz (2019), çalışmalarında BİST Sürdürülebilirlik Endeksinde bulunan işletmelerin sosyal sorumluluk, çevre ve sürdürülebilirlik faaliyetlerini incelemişlerdir. Ayrıca, işletmelerin sosyal sorumluluk açısından çevresel duyarlılıklarının seviyelerini tespit etmeye çalışmışlardır. Çalışmada, BİST Sürdürülebilirlik Endeksi 2017 yll değerlemeye tabi tutulmuş ve işletmelerin finansal tabloları ve faaliyet raporları incelenmiştir. Araştırma yöntemi olarak içerik analizi kullanılmıştır. Çalışma sonucunda, işletmelerin çevre muhasebesi uygulamadıkları, finansal raporlarında ve sürdürülebilirlik raporlarında çevre ile ilgili sayısal bilgilerden ziyade genel bilgilerin bulunduğu tespit edilmiştir.

\section{KURUMSAL SOSYAL SORUMLULUK KAVRAMI VE ÖNEMİ}

Kurumsal sosyal sorumluluk (KSS) kavramını oluşturan kurumsal kavramı "tüzel bir kişiliğe sahip olan şirketlere iliş̧in" bir kavram olarak nitelendirilmektedir. $\mathrm{Bu}$ nitelendirmeye bağlı olarak kişilerle, organizasyonlarla ve resmi kuruluşlarla ilişkilendirilen sosyal sorumluluk kavramından farklı olarak kurumsal sosyal sorumluluk kavramı "işletmelerin topluma sağladıkları yarar" ile incelenen bir kavram niteliğini teşkil etmektedir (Sarıkaya ve Akarca, 2011:61; Pusak, 2014:5). Kurumsal sosyal sorumluluk kavramı; işletmenin, toplumun beklentilerine cevap vermesinde gönüllülük esasına dayanarak, ekonomik unsurların dişında insani unsurlara da önem vermesidir (Yalman, 2018:8). Kurumsal sosyal sorumluluğun kesin ve somut bir tanımı olmamasına rağmen, çeşitli yönetim disiplinleri, kurumsal sosyal sorumluluğun kalite yönetimi, pazarlama, iletişim, finans, insan kaynakları yönetimi ve raporlama gibi disiplinlerin amaçlarına uygun olduğunu kabul etmişlerdir. Tablo 1. içerisinde kurumsal sosyal sorumluluğun literatürde en sık 
alıntı yapılan tanımlarından bazıları yer almaktadır (Dusuki ve Yusof, 2008: 30).

Tablo 1. Kurumsal Sosyal Sorumluluğun Önerilen Tanımları

\begin{tabular}{|c|c|}
\hline Yazar/lar & Önerilen Kurumsal Sosyal Sorumluluk Tanımları \\
\hline $\begin{array}{l}\text { Bowen (1953) ve } \\
\text { Carroll (1999) }\end{array}$ & $\begin{array}{l}\text { İş adamlarının politikaları takip ederek karar vermesi veya } \\
\text { toplumun hedefleri ve değerleri açısından arzu edilen eylem } \\
\text { çizgilerini takip etme yükümlülüğü. }\end{array}$ \\
\hline Davis (1960) & $\begin{array}{l}\text { Firmanın doğrudan ekonomik veya teknik ilgisinin ötesinde } \\
\text { bazı nedenlerden dolayı iş adamlarının aldığı kararlar ve } \\
\text { eylemler. }\end{array}$ \\
\hline Davis (1973) & $\begin{array}{l}\text { Firmanın, dar ekonomik, teknik ve yasal gerekliliklerinin } \\
\text { ötesindeki hususları dikkate alması ve bunlara yanıt vermesi. }\end{array}$ \\
\hline Fitch (1976) & $\begin{array}{l}\text { Kurumun sosyal problemleri çözmeye yönelik tamamen veya } \\
\text { kısmen ciddi girişimlerde bulunması. }\end{array}$ \\
\hline Zenisek (1979) & $\begin{array}{l}\text { Toplumun iş dünyası beklentileri ile iş ahlakı arasındaki } \\
\text { "uygunluk" derecesi. }\end{array}$ \\
\hline Jones (1980) & $\begin{array}{l}\text { Kurumların, hissedarları dışında toplumda kanun ve sendika } \\
\text { sözleşmeleri ile öngörülenlerin ötesinde gruplar kurma } \\
\text { zorunluluğu. }\end{array}$ \\
\hline Epstein (1989) & $\begin{array}{l}\text { Ticari organizasyonların, kıt mal ve hizmet üretme ve } \\
\text { dağıtma ișlevlerinin hissedarlar için ekonomik olarak tatmin } \\
\text { edici bir düzeyde kâr getirmelerini aşan toplumsal } \\
\text { yükümlülükler. }\end{array}$ \\
\hline Maclagan (1999) & $\begin{array}{l}\text { Bireylerin ahlaki değerlerinin ve kaygılarının dile getirildiği } \\
\text { süreç. }\end{array}$ \\
\hline $\begin{array}{l}\text { McWilliams ve Siegel } \\
(2001) ; \\
\text { Kok ve diğ. ark. (2001) }\end{array}$ & $\begin{array}{l}\text { Firmanın kaynaklarını topluma fayda sağlayacak şekilde } \\
\text { kullanma yükümlülüğu veya toplumun bir üyesi olarak } \\
\text { kararlı katılım yoluyla toplumu genel olarak dikkate alarak ve } \\
\text { șirketin doğrudan kazanımlarından bağımsız olarak } \\
\text { toplumun refahını iyileștirme yükümlülüğü. }\end{array}$ \\
\hline
\end{tabular}

Kaynak: (Dusuki ve Yusof, 2008: 31)

1953 yılında Amerikalı iktisatçı Howard Bowen'in yayınladığı "İş Adamının Sosyal Sorumlulukları" (Social Responsibilities of the Businessman) adlı makalesiyle kurumsal sosyal sorumluluk kavramının temelleri atılmıștır (Garriga ve Mele, 2004:51). Bowen bu makalesinde, işletme sahiplerinin toplumun değer ve hedefleriyle örtüșen sosyal sorumluluk çalışmalarına yönelmeleri ve bu faaliyetlerle ilgilenmeleri gerektiği görüşünü savunmaktadır (Aktan ve Börü, 2007:6). Kurumsal sosyal sorumluluk kavramının temellerinin atılmasının ardından birey odaklı kârlılık ve sürekliliğinin sağlanması düşüncesi bütün dünyada değişime uğramaya başlamıştır. İşletmenin sadece kâr elde etmesi ve çevre ile topluma yönelik sorunlara fazla önem vermemesi görüşü, yerini işletmenin tek amacının kâr sağlamak olmadığı çevreye ve topluma karşı da sorumlulukları olduğu görüșüne bırakmıștır (Bayraktaroğlu İlter ve Tanyeri, 2009:35). Bilgi teknolojilerinde yașanan ilerlemelerle birlikte toplumda gelișmeye başlamış ve işletmeler toplumun refah düzeyini arttırıcı çalışmalara yönelmişlerdir. İnsani değerlerin önem kazanması ve artan eğitimle birlikte bireylerin refah düzeyindeki artışlar, bireylerin beklentilerinin de artmasını sağlamıştır. İşletmelerin kâr elde edebilmesi ve sürekliliğini 
sağlayabilmesi için kurumsal sosyal sorumluluk faaliyetleri zorunlu bir hal almaya başlamıştır (Alkan, 2004:5). Son zamanlarda daha fazla ilgi görmeye başlayan çevre kirliliği, hammadde ve enerjideki eksiklikler, işletmelerin tekel niteliği kazanması, siyasi sorunlar, işletmenin iç ve dış çevresinde yaşanan sorunlar bağlamında işletmeler toplumsal fayda sağlayan çalışmalara yönelmişlerdir (Korkmaz, 2009:33). Toplum ve iş dünyası arasında yaşanan ciddi değişikliklerde kurumsal sosyal sorumluluk sürecinin gelişmesinde aktif bir rol oynamıştır. Kurumsal sosyal sorumluluğun yaygınlaşmasında Dünya Bankası, Ekonomik İşbirliği ve Kalkınma Teşkilatı, Birleşmiş Milletler, Avrupa Birliği ve diğer uluslararası kuruluşların önemli etkisi bulunmaktadır. Nitekim Avrupa Birliği tarafından 2005 yılı da "Kurumsal Sosyal Sorumluluk Yılı" olarak ilan edilmiştir (Akgeyik, 2007:66; Bayraktaroğlu vd., 2009:36).

Günümüzde kurumsal sosyal sorumluluk çalışmalarının sağlık, eğitim, çevre ve topluma destek uygulamaları üzerine yoğunlaştı̆̆ı görülmektedir. Bu uygulamaları ayrıntılı şekilde ifade etmek gerekirse; yaşam standardının yükselmesi, toplumsal açıdan yaşamı kolaylaştırma, bölgesel kalkınmayı destekleme, toplumsal güven, doğal çevreyi koruma, istihdam olanakları, kültürel varlıkların korunması ve gelecek nesillere ulaşmasını sağlama, çevreye yönelik yatırımlar ve yeni doğal alanlar oluşturma gibi geniş bir uygulama alanına sahiptir (Gürel, 2010:118). Kurumsal sosyal sorumluluk faaliyetleri gönüllülük esasına dayanan faaliyetlerdir. Ancak, tamamen karşıllı beklemeksizin yapılan faaliyetler olduğunu ileri sürmek gerçeği yansıtmamaktadır. Çünkü kurumsal sosyal sorumluluk faaliyetleri iktisadi ve sosyal geri dönüş sağlayan yönetim faaliyetleridir (Saran, Coşkun, Zorel ve Aksoy, 2011:3735). İşletmelerin geleceği içinde önemli bir yatırım aracı olarak görülmektedir. İșletmelerin toplumun ihtiyaçlarına odaklanarak, toplumsal sorunlara destek vermesi ve çözüm arayışında olması işletmeye hem maddi hem de manevi olarak olumlu getiriler sağlamaktadır. İşletmeler kurumsal sosyal sorumluluk çalışmaları ile rakiplerine karşı rekabet üstü avantaj sağlarken toplum nezdinde de iyi bir itibar ve imaj kazanmaktadırlar (Fidan ve Şentürk, 2017:41).

İșletmelerin stratejik yönetim süreçlerinde, misyon, vizyon ve değer anlayışları içerisinde kurumsal sosyal sorumluluğa yer vermeleri bu kavrama verdikleri önemi göstermektedir. Ancak burada dikkat edilmesi gereken husus, işletmelerin bu değerleri uygulamaya geçirebilmeleridir. Bu bağlamda, işletmeler kurumsal sosyal sorumluluk faaliyetlerine var oluş sebepleri arasında yer veriyorlarsa, bunu bütün faaliyetlerine yansıtmaları gerekmektedir. Aksi takdirde işletmelerin, kurumsal sosyal sorumluluk faaliyetleri ilgi çekme çabasından öteye gidemeyecektir. Bu durumda toplumun, işletmeye karşı olan güvenini yitirmesine sebep olacaktır (Gümüş ve Öksüz, 2009:21-35).

İşletmelerin kurumsal sosyal sorumluluk kapsamında ilişki içerisinde olduğu çıkar grupları bulunmaktadır. Bu çıkar gruplarının bazıları işletmeyle doğrudan ilişki içerisinde bulunurken, bazıları da dolaylı olarak ilişki içerisinde bulunmaktadır. İşletmenin çevresi olarak da nitelendirilen bu çıkar grupları, işletmenin iç ve dış çevresi olarak adlandırılmaktadır (Korkmaz, 2009:47). İşletmenin iç çevresi içerisinde; hissedarlar ve çalışanlara yönelik 
sorumluluklar yer alırken, dış çevresi içerisinde ise; müşteriler, tedarikçiler, çevre, devlet, rakipler ve topluma yönelik sorumluluklar yer almaktadır. İşletme ise hem iç hem de diş çıkar grupları arasında yer almakta ve kurumsal sosyal sorumluluğunu her iki tarafin da beklenti ve isteklerini karşlayacak şekilde dengelemeye çalışmaktadır (Aktan ve Börü, 2007:10). Topluma ve çevreye karşı duyarlı davranan, saygılı ve etik değerlere uygun işletmeler, tüketiciler tarafından daha fazla ilgi görmektedirler. $\mathrm{Bu}$ ilgi toplumun gelişmişlik seviyesiyle doğru orantılı bir şekilde artmaktadır. İşletmeler için birçok fon sağlayan ve yatırım yapan kuruluşlar da işletmeleri sorumluluk performansları çerçevesinde değerlendirmektedir. Bu doğrultuda, kurumsal sosyal sorumluluk faaliyeti yürüten ișletmeler rekabet ve sermaye avantajı kazanmaktadırlar (Șahin, 2019:18; Șahinolanlar, 2015:10). Birleșmiș Milletler, Avrupa Birliği ve Uluslararası Çalışma Örgütü gibi organizasyonlar tarafından çevrenin, toplumun, çalışanların ve işletmenin diğer çıkar gruplarına yönelik geliştirilmiş olan koruyucu davranışları, kurumsal sosyal sorumluluk kavramının önemini ortaya koymaktadır (Ece, 2019:43-58).

\section{ARAŞTIRMANIN METODOLOJİSi}

Çalışmanın bu bölümünde araştırmanın temel amacı ve kapsamı belirtilerek, kullanılan yöntem doğrultusunda içerik analizi sürecinin aşamaları uygulanarak, elde dilen anlamlı bulgular paylaşılmıştır.

\subsection{Araștırmanın Amacı}

$\mathrm{Bu}$ çalışmanın amacı, BİST 100 Endeksinde yer alan işletmelerin kurumsal sosyal sorumluluk çalışmalarının BIST 30, BIST 50 ve BİST 100 endeksleri ve sektörler açısından karşılaştırmalı bir içerik analizinin yapılarak elde edilen anlamlı sonuçların paylaşılmasıdır. Çalış̧ma kapsamında BİST 100 endeksinde yer alan işletmelerin kurumsal internet siteleri ve sürdürülebilirlik raporları taranarak içerik analizine tabi tutulmuştur. Bu kapsamda 77 işletmenin güvenilir ve kamuya açık 2018 ve 2019 yılları arasındaki rapor ve uygulamalarına ulaşılarak analize dâhil edilmiştir.

\subsection{Yöntem}

Çalışmada kurumsal sosyal sorumluluk çalışmalarının incelenmesi için uygun araçlar sunan nitel araştırma yöntemlerinden içerik analizi kullanılmıştır. Nitel araştırma yöntemleri veri analizinde farklı desenleri ve özgün aşamaları gerektiren imgesel verilere ihtiyaç duymaktadır (Creswell, 2014:183). Çalışma kapsamında kullanılan içerik analizi yöntemi, birbirine benzeyen verileri belirli kavramlar ve temalar çerçevesinde bir araya getirerek bunları okuyucunun anlayabileceği bir şekilde düzenlemek ve yayımlamak esasına dayanmaktadır (Demirel, 2018:73). Kurumsal sosyal sorumluluk ölçümünün sınır ve içeriğinin tanımlanması açısından oldukça zor olduğu bilinmektedir. Bu çerçevede kurumsal sosyal sorumluluk ölçümünde içerik analizi, itibar endeksi, KLD (Domini 400) endeksi ve zehirli atık endeksi en sık tercih edilen yöntemler arasında sıralanmaktadır (Sarıkaya ve Akarca, 2011:65-66). Çalışmanın geçerlilik ve güvenilirliğini arttırmak amacıyla Tablo 2 içerisinde yer alan içerik analizinin aşamaları takip edilmiştir. 
Tablo 2. İçerik Analizinin Așamaları

\begin{tabular}{|c|}
\hline IÇERIK ANALizi SÜRECi \\
\hline Araştırma yapısı ve sorularını oluşturma \\
\hline Belgenin kaynağını tanımlama \\
\hline Analiz birimi ve örneklemi belirtme \\
\hline Kodlama çerçevesini belirleme \\
\hline Verileri analiz etme \\
\hline
\end{tabular}

Kaynak: (Popping, 2000:10-11; Harris, 2001:194; Chun, 2019:61; Aytar, 2019:327'den uyarlanmıştır.)

\subsubsection{Araştırma Yapısı ve Sorularını Oluşturma}

BİST 100 içerisinde yer alan işletmelerin farklı sektörlerde faaliyet yürütmeleri ve daha özelde BİST 30 ve BİST 50 endekslerinde yer almaları bu endeksler ve sektörler arasında farklı açılardan karşılaştırmaların yapılmasını mümkün kılmaktadır. Çalışmanın amaçları çerçevesinde aşağıda yer alan araştırma sorularına cevap bulunmaya çalıșılmıștır.

1. BİST 100 Endeksi içerisinde yer alan işletmelerin KSS faaliyetleri hangi faaliyet türleri üzerine yoğunlaşmaktadır? Önceden belirlenen temalar açısından sektör bazında nasıl bir dağılım gerçekleșmektedir?

2. BIST 100, BIST 50 ve BIST 30 Endekslerinin belirlenen temalar açısından yoğunlaştıkları KSS faaliyetleri arasında fark bulunmakta mıdır? Endeks özelinde KSS faaliyetleri hangi faaliyet türleri üzerine yoğunlaşmaktadır?

\subsubsection{Belgenin Kaynağını Tanımlama}

Araştırmanın ana kütlesini, Nisan-Haziran 2020 dönemine ait BİST 100 Endeksinde yer alan işletmeler oluşturmaktadır. Araştırmada tam sayım yöntemi kullanılmıştır. BIST endekslerinde yer alan işletmelerin listesine KAP (Kamuyu Aydınlatma Platformu)'ın resmi internet sayfasından ulaşılmıştır. Araştırma kapsamında BIST 100 Endeksinde yer alan işletmelerin seçilmesinin nedeni, Türkiye'nin en yüksek piyasa değerine, en yüksek borsa işlem hacmine ve ideal kurumsal yönetim standartlarına sahip olduklarının bilinmesidir. Dolayısıyla bu işletmelerin KSS faaliyetlerine kurumsal internet sitelerinde yer verdikleri ve sürdürülebilirlik raporlarını düzenli aralıklarla yayınladıkları düşünülmektedir. Araştırma kapsamında Nisan-Haziran 2020 dönemi BİST 100 içindeki şirketlerin 2018 ve 2019 yılları içinde alt tema ayrıntıları özelinde endeks ve sektör açısından hangi KSS ana temalarına daha fazla ağırlık verdikleri belirlenmeye çalıșllmıștır.

\subsubsection{Kodlama Çerçevesini Belirleme}

$\mathrm{Bu}$ çalışmada kodlama çerçevesinin belirlenmesinde BİST 100 Endeksinde yer alan işletmelerin sürdürülebilirlik raporları referans olarak 
kabul edilmiștir. Bu konuda Aytar (2019), tarafından daha önce sürdürülebilirlik raporları referans alınarak yapılan benzer bir araștırmaya paralel olarak sosyal ve kültürel, çevresel, eğitim odaklı, toplum sağlığına yönelik ve enerji verimliliği konuları ana kategoriler olarak belirlenmiştir. $\mathrm{Bu}$ ana kategorilerle birlikte KSS uygulamalarıyla ilişkili olan alt kategoriler de tespit edilmiştir. Belirlenen alt kategoriler kurumsal sosyal sorumluluk faaliyetleri adı altında kodlanmıştır. Çalışma çerçevesinde yapılan kodlamalar Microsoft Excel dosyasında oluşturulan bir kodlama formuna kayıt edilmiş, analiz sürecinde Nvivo nitel analiz programından faydalanılmıştır. Çalışma kapsamında kurumsal sosyal sorumluluk faaliyetleri Tablo 3 içinde yer alan ana kategoriler ve bu ana kategorilerin alt kategorileri içeriği açısından taranarak kodlanmıștır.

Tablo 3. Kurumsal Sosyal Sorumluluk Faaliyetleri Kodlama Tablosu

$\begin{array}{cc}\text { FAALIYET İÇERIĞ́̇ } & \text { KSS FAALIYET TÜRÜ } \\ \text { KODLAMASI (1) } & \text { KODLAMASI (2) }\end{array}$

(a1) Görsel, İșitsel ve Dramatik Sanatların

Gelişimi ve Desteklenmesine Yönelik

Faaliyetler;

(a2) Turizm ve Tarım Gibi Sektörel

Alanların Gelișimi ve Desteklenmesine

Yönelik Faaliyetler;

(a3) Çocuk, Aile ve Cinsiyet Eşitliğine Odaklanan Sosyal Projelerin

Desteklenmesine Yönelik Faaliyetler;

(a4) Sosyal ve Kültürel Faaliyetler

Kapsamında Değerlendirilen Burs, Bağıș ve

Destekler;

(a5) Bireylerin Sportif Etkinliklerle Sosyal Gelişimine Yönelik Faaliyetler;

(a6) Bireylerin Daha Güvenli Yaşam

İmkânlarına Yönelik Faaliyetler;

(a7) Dezavantajlı Grupların

Desteklenmesine Yönelik Faaliyetler;

(a8) Kültürel Mirasın Korunmasına Yönelik Faaliyetler

(b1) Ağaçlandırma Faaliyetleri;

(b2) Doğa, Çevre ve Biyoçeşitliliğin

Korunması Faaliyetleri;

Ana Tema:

Sosyal ve Kültürel Faaliyetler

Alt Tema:

$(A)=(a 1, a 2, a 3, a 4, a 5, a 6, a 7, a 8)$

(b3) Karbon İzi Azaltma Faaliyetleri;

Çevresel Faaliyetler

(b4) Yaban ve Sokak Hayvanlarına Yönelik

Alt Tema:

$(B)=(b 1, b 2, b 3, b 4)$ 
Faaliyetler

(c1) Öğrencilerin Bilgi ve Yeteneklerinin

Gelișmesine Yönelik Eğitim Odaklı

Faaliyetler;

(c2) Bilimsel Çabaların Desteklenmesine Yönelik Faaliyetler;

Ana Tema:

(c3) Okuma Alışkanlığı ve Kitap

Ulaşllabilirliğini Artırmaya Yönelik

Faaliyetler;

Eğitim Odaklı Faaliyetler

Alt Tema:

$(C)=(c 1, c 2, c 3, c 4, c 5, c 6)$

(c4) Aile, Öğretmen ve Öğrenci Odaklı

Eğitim Faaliyetleri;

(c5) Diğer Eğitim Faaliyetleri;

(c6) Eğitim Kapsamında Değerlendirilen

Burslar, Bağıș ve Destekler

(d1) Genel Olarak Toplum Sağlığını

İyileştirmeyi Amaçlayan Faaliyetler;

(d2) Dezavantajlı Grupların Rehabilite

Edilmesine Yönelik Faaliyetler

Ana Tema:

Toplum Sağlığı Faaliyetleri

Alt Tema:

(D) $=(\mathrm{d} 1, \mathrm{~d} 2)$

(e1) Enerji Verimliliğini Artırmaya Yönelik

Faaliyetler;

Ana Tema:

(e2) Temiz Enerji Bilincinin

Oluşturulmasına Yönelik Faaliyetler

Enerji Verimliliği Faaliyetleri

Alt Tema:

$(E)=(e 1, e 2)$

Kaynak: (Aytar, 2019:330'dan Genişletilmiştir.)

\subsubsection{Verilerin Analiz Edilmesi ve Bulgular}

Çalışma kapsamında BIST 100 Endeksinde yer alan işletmelerin sürdürülebilirlik raporları, kurumsal internet siteleri ve basında yer alan kurumsal sosyal sorumluluk faaliyetleri ayrıntılı bir analize tabi tutulmuştur. Elde edilen veriler Tablo 3. içinde gösterilen ana ve alt tema başlıkları altında kodlanmıştır. Kodlama işlemi tamamlandıktan sonra endeks ve sektör grupları kurumsal sosyal sorumluluk ana tema ve alt tema başlıklarına göre karşılaştırmalar yapılarak anlamlı sonuçlar elde edilmiştir. 
Grafik 1. BİST 100 İșletmelerinin Yoğunlaştıkları KSS Faaliyet Türleri

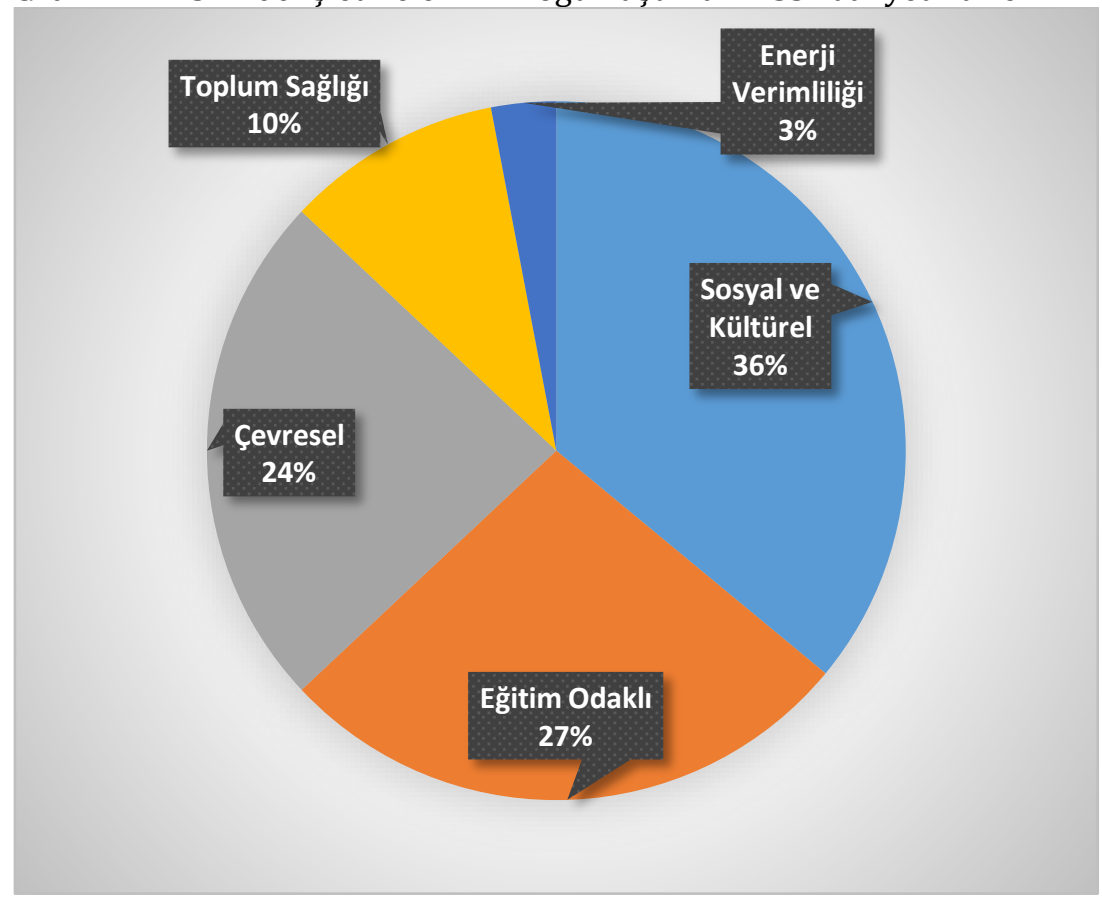

Grafik 1'de detayları gösterilen BİST 100 Endeksindeki işletmelerin kurumsal sosyal sorumluluk faaliyetlerinin genel olarak sosyal ve kültürel faaliyetlere yoğunlaştığı görülmektedir. BIST 100 Endeksinde yer alan işletmelerin \%36'sının (60 İşletme) kurumsal sosyal sorumluluk kapsamında en az bir sosyal ve kültürel faaliyete; $\% 27$ 'sinin ( 52 İşletme) en az bir eğitim odaklı faaliyete; \%24'ününde (48 İşletme) en az bir çevresel faaliyete yönelik kurumsal sosyal sorumluluk çalışması gerçekleștirdiği görülmektedir. Yine bu ișletmelerden \%10'nun (26 İşletme) en az bir toplum sağlığına yönelik kurumsal sosyal sorumluluk faaliyeti gerçekleştirdiği ve \%3'ününde (9 İşletme) enerji verimliliği faaliyetlerine yönelik kurumsal sosyal sorumluluk çalışmalarına imza attıkları görülmektedir. BIST 100 Endeksinde yer alan işletmelerin kurumsal sosyal sorumluluk faaliyetleri kapsamında ana kategorilerinin altında yer alan KSS uygulamalarıyla ilișkili olan alt kategorilere ne düzeyde yer verdikleri Tablo 4 içerisinde paylaşılmıştır. 
Tablo 4. Kurumsal Sosyal Sorumluluk Alt Kategorileri Türlerinin Dağılımı (BİST 100)

\begin{tabular}{|c|c|c|c|c|}
\hline \multicolumn{5}{|c|}{ BİST 100 Endeksi KSS Faaliyet Türleri } \\
\hline $\begin{array}{l}\text { Sosyal ve } \\
\text { Kültürel } \\
\text { Faaliyetler } \\
\end{array}$ & $\begin{array}{l}\text { Çevresel } \\
\text { Faaliyetler }\end{array}$ & $\begin{array}{l}\text { Eğitim } \\
\text { Odaklı } \\
\text { Faaliyetler }\end{array}$ & $\begin{array}{l}\text { Toplum } \\
\text { Sağllğı } \\
\text { Faaliyetleri }\end{array}$ & $\begin{array}{l}\text { Enerji } \\
\text { Verimliliği } \\
\text { Faaliyetleri }\end{array}$ \\
\hline (a1) $=\% 27$ & $(\mathrm{~b} 1)=\% 38$ & (c1) $=\% 14$ & $(\mathrm{~d} 1)=\% 53$ & $(\mathrm{e} 1)=\% 100$ \\
\hline$(\mathrm{a} 2)=\% 5$ & (b2) $=\% 43$ & $(\mathrm{c} 2)=\% 2$ & $(\mathrm{~d} 2)=\% 47$ & $(\mathrm{e} 2)=\% 0$ \\
\hline (a3) $=\% 10$ & (b3) $=\% 8$ & $(\mathrm{c} 3)=\% 8$ & & \\
\hline$(\mathrm{a} 4)=\% 20$ & $(\mathrm{~b} 4)=\% 11$ & $(\mathrm{c} 4)=\% 5$ & & \\
\hline$(\mathrm{a} 5)=\% 12$ & & $(\mathrm{c} 5)=\% 41$ & & \\
\hline$(\mathrm{a} 6)=\% 4$ & & $(\mathrm{c} 6)=\% 30$ & & \\
\hline \multicolumn{5}{|l|}{ (a7) $=\% 10$} \\
\hline$(\mathrm{a} 8)=\% 12$ & & & & \\
\hline
\end{tabular}

BİST 100 Endeksinde yer alan işletmelerin kurumsal sosyal sorumluluk açısından sosyal ve kültürel faaliyetler kapsamında ana kategorilerinin altında yer alan KSS uygulamalarıyla ilişkili olan alt kategorilerden en fazla (a1) görsel, işitsel ve dramatik sanatların gelişimi ve desteklenmesine yönelik faaliyete (\%27) yoğunlaştıkları anlaşılmaktadır. Bu faaliyetler içerisinde; sergi, konser, kısa film festivali, tiyatro, sinema, belgesel, müze çalışması gibi organizasyonlar gerçekleștirilmiştir. BIST 100 Endeksinde yer alan işletmelerin kurumsal sosyal sorumluluk açısından eğitim odaklı faaliyetler kapsamında ana kategorilerinin altında yer alan KSS uygulamalarıyla ilişkili olan alt kategorilerden en fazla (c5) diğer eğitim faaliyetlerine (\%41) yoğunlaştıkları anlaşılmaktadır. Diğer eğitim faaliyetleri içerisinde; üniversite, vakıf ve derneklerle yürütülen öğrencilerin yetkinliklerini arttırmaya yönelik faaliyetler, kariyer programları, okullara ekipman desteklerinin sağlanmasına yönelik çalışmalar bulunmaktadır. BİST 100 Endeksinde yer alan işletmelerin kurumsal sosyal sorumluluk açısından çevresel faaliyetler kapsamında ana kategorilerinin altında yer alan KSS uygulamalarıyla ilişkili olan alt kategorilerden en fazla (b2) doğa, çevre ve biyoçeşitliliğin korunmasına yönelik faaliyetlere (\%43) yoğunlaştıkları anlaşılmaktadır. Bu faaliyetler içerisinde; çevre temizliği çalışmaları, ambalaj atıklarının geri kazanımı gibi çalışmalar yer almaktadır. BISTT 100 Endeksinde yer alan işletmelerin kurumsal sosyal sorumluluk açısından toplum sağlığına yönelik faaliyetler kapsamında ana kategorilerinin altında yer alan KSS uygulamalarıyla ilişkili olan alt kategorilerden en fazla (d1) toplum sağlığını iyileştirmeyi amaçlayan çalışmalara (\%53) yoğunlaştıkları anlaşılmaktadır. Bu faaliyetler içerisinde; ihtiyaç sahibi hastaların desteklenmesi, tedavi programları, ilaç yardımı, kan bağışı gibi çalışmalar yer almaktadır. BİST 100 Endeksinde yer alan işletmelerin kurumsal sosyal sorumluluk faaliyetleri açısından enerji verimliliği faaliyetleri kapsamında en fazla (e1) enerji verimliliğini artırmaya yönelik çalışmalara yer verdikleri tespit edilmiştir. 
Grafik 2. BİST 50 İşletmelerinin Yoğunlaştıkları KSS Faaliyet Türleri

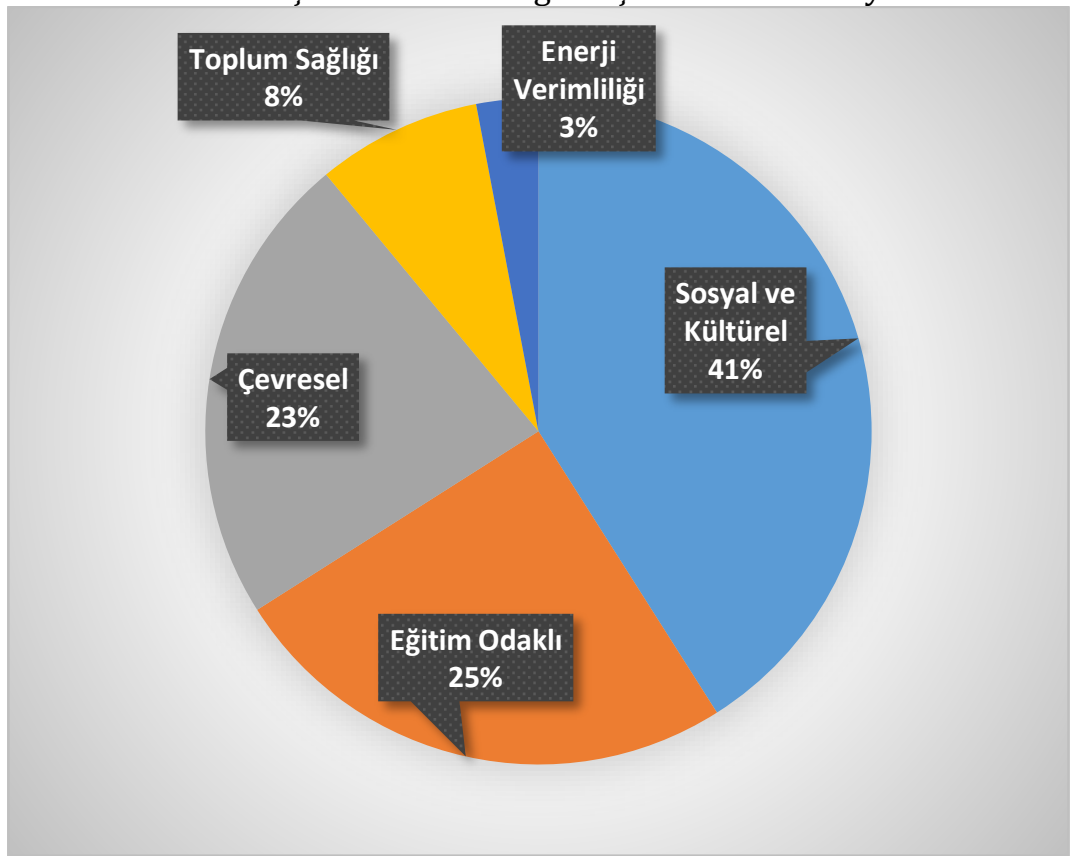

Grafik 2'de detayları gösterilen BIST 50 Endeksindeki işletmelerin kurumsal sosyal sorumluluk faaliyetlerinin genel olarak sosyal ve kültürel faaliyetlere yoğunlaştığı görülmektedir. BİST 50 Endeksinde yer alan işletmelerin \%41'inin (36 İşletme) kurumsal sosyal sorumluluk kapsamında en az bir sosyal ve kültürel faaliyete; \%25'inin (29 İşletme) en az bir eğitim odaklı faaliyete; \%23'ünün de (26 İşletme) en az bir çevresel faaliyete yönelik kurumsal sosyal sorumluluk çalışması gerçekleştirdikleri görülmektedir. Yine bu işletmelerden \%8'inin (11 İşletme) en az bir toplum sağlığına yönelik kurumsal sosyal sorumluluk faaliyeti gerçekleștirdiği ve \%3'ünün de (5 İşletme) enerji verimliliği faaliyetlerine yönelik kurumsal sosyal sorumluluk çalışmalarına imza attıkları görülmektedir. BİST 50 Endeksinde yer alan ișletmelerin kurumsal sosyal sorumluluk faaliyetleri kapsamında ana kategorilerinin altında yer alan KSS uygulamalarıyla ilişkili olan alt kategorilere ne düzeyde yer verdikleri Tablo 5 içerisinde paylaşılmıştır.

Tablo 5. Kurumsal Sosyal Sorumluluk Alt Kategori Türlerinin Dağılımı (BIST 50) 


\begin{tabular}{l|l|l|l|l}
\hline $\begin{array}{l}\text { Sosyal ve } \\
\text { Kültürel } \\
\text { Faaliyetler }\end{array}$ & $\begin{array}{l}\text { Çevresel } \\
\text { Faaliyetler }\end{array}$ & $\begin{array}{l}\text { Eğitim Odaklı } \\
\text { Faaliyetler }\end{array}$ & $\begin{array}{l}\text { Toplum } \\
\text { Sağllğı } \\
\text { Faaliyetleri }\end{array}$ & $\begin{array}{l}\text { Enerji } \\
\text { Verimliliği } \\
\text { Faaliyetleri }\end{array}$ \\
\hline (a1) $=\% 24$ & (b1) $=\% 42$ & $(\mathrm{c} 1)=\% 13$ & $(\mathrm{~d} 1)=\% 50$ & $(\mathrm{e} 1)=\% 100$ \\
\hline$(\mathrm{a} 2)=\% 5$ & $(\mathrm{~b} 2)=\% 44$ & $(\mathrm{c} 2)=\% 0$ & $(\mathrm{~d} 2)=\% 50$ & $(\mathrm{e} 2)=\% 0$ \\
\hline (a3) $=\% 11$ & $(\mathrm{~b} 3)=\% 7$ & $(\mathrm{c} 3)=\% 6$ & & \\
\hline$(\mathrm{a} 4)=\% 17$ & $(\mathrm{~b} 4)=\% 7$ & $(\mathrm{c} 4)=\% 8$ & & \\
\hline$(\mathrm{a} 5)=\% 14$ & & $(\mathrm{c} 5)=\% 45$ & & \\
\hline$(\mathrm{a})=\% 4$ & & $(\mathrm{c} 6)=\% 28$ & & \\
\hline$(\mathrm{a})=\% 12$ & & & & \\
\hline$(\mathrm{a})=\% 13$ & & & & \\
\hline
\end{tabular}

BIST 50 Endeksinde yer alan işletmelerin kurumsal sosyal sorumluluk açısından sosyal ve kültürel faaliyetler kapsamında ana kategorilerinin altında yer alan KSS uygulamalarıyla ilişkili olan alt kategorilerden en fazla (a1) görsel, işitsel ve dramatik sanatların gelişimi ve desteklenmesine yönelik faaliyetlere (\%24) yoğunlaştıkları tespit edilmiştir. BİST 50 Endeksinde yer alan işletmelerin kurumsal sosyal sorumluluk açısından eğitim odaklı faaliyetler kapsamında ana kategorilerinin altında yer alan KSS uygulamalarıyla ilişkili olan alt kategorilerden en fazla (c5) diğer eğitim faaliyetlerine (\%45) yoğunlaștıkları anlașılmaktadır. BİST 50 Endeksinde yer alan ișletmelerin kurumsal sosyal sorumluluk açısından çevresel faaliyetler kapsamında ana kategorilerinin altında yer alan KSS uygulamalarıyla ilişkili olan alt kategorilerden en fazla (b2) doğa, çevre ve biyoçeşitliliğin korunması, çevre kirliliğinin önlenmesi ve atıkların geri dönüşümüne yönelik faaliyetlere (\%44) yoğunlaştıkları anlaşılmaktadır. BİST 50 Endeksinde yer alan işletmelerin kurumsal sosyal sorumluluk açısından toplum sağlığına yönelik faaliyetler kapsamında ana kategorilerinin altında yer alan KSS uygulamalarıyla ilişkili olan alt kategorilerden toplum sağlığını iyileştirmeyi amaçlayan çalışmalar (\%50) ile dezavantajlı grupların rehabilite edilmesine yönelik çalıșmalara (\%50) eşit düzeyde yoğunlaştıkları anlaşılmaktadır. BiST 50 Endeksinde yer alan işletmelerin kurumsal sosyal sorumluluk açısından enerji verimliliğine yönelik faaliyetler kapsamında ana kategorilerinin altında yer alan KSS uygulamalarıyla ilişkili olan alt kategorilerden en fazla enerji verimliliğini artırmaya yönelik faaliyetlere yer verdikleri ve temiz enerji bilincinin oluşturulmasına yönelik faaliyetlere yer vermedikleri tespit edilmiștir. 
Grafik 3. BİST 30 İşletmelerinin Yoğunlaştıkları KSS Faaliyet Türleri

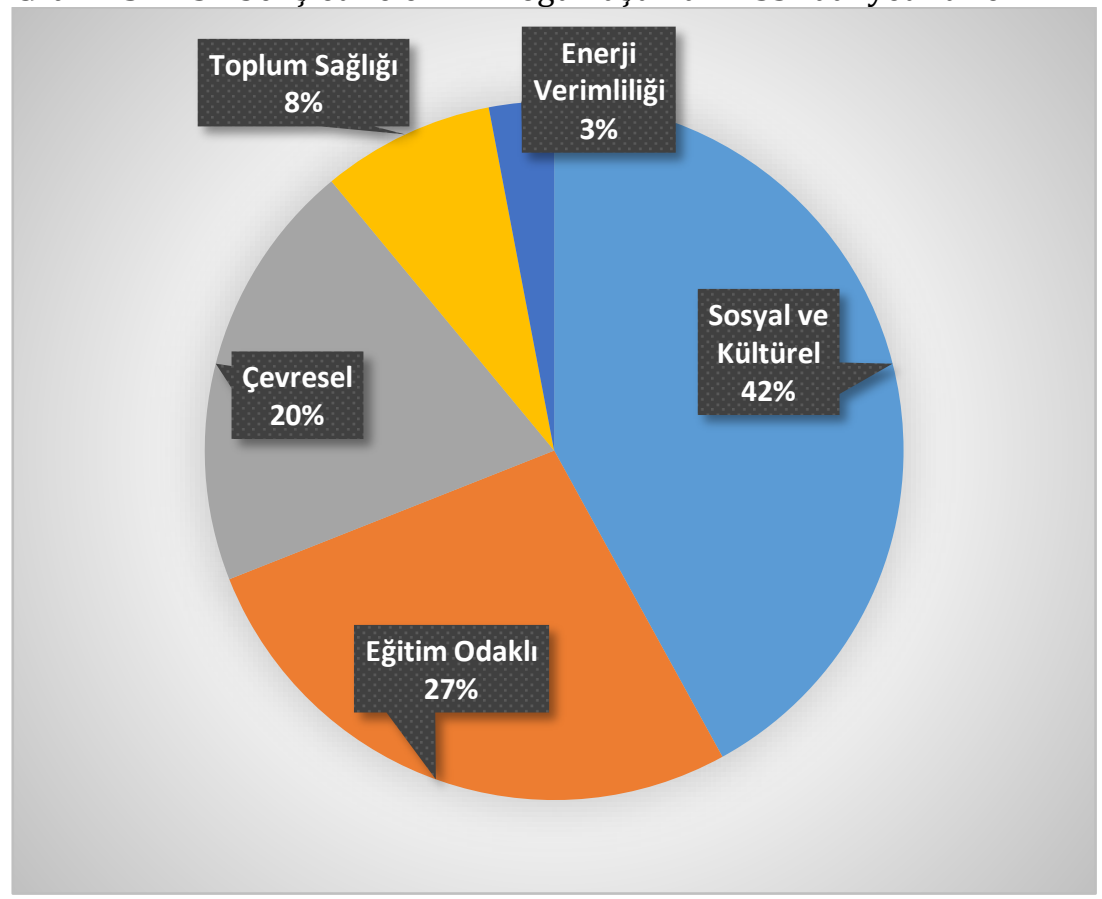

Grafik 3'de detayları belirtilen BíST 30 Endeksindeki işletmelerin kurumsal sosyal sorumluluk faaliyetlerinin genel olarak sosyal ve kültürel faaliyetlere yoğunlaştığı görülmektedir. BİST 30 Endeksinde yer alan işletmelerin \%42'sinin (22 İşletme) kurumsal sosyal sorumluluk kapsamında en az bir sosyal ve kültürel faaliyete; \%27'sinin (19 İşletme) en az bir eğitim odaklı faaliyete; \%20'sinin de (15 İşletme) en az bir çevresel faaliyete yönelik kurumsal sosyal sorumluluk çalışması gerçekleștirdikleri görülmektedir. Yine bu işletmelerden \%8'inin (7 İşletme) en az bir toplum sağlığına yönelik kurumsal sosyal sorumluluk faaliyeti gerçekleștirdiği ve \%3'ünün de (3 İşletme) enerji verimliliği faaliyetlerine yönelik kurumsal sosyal sorumluluk çalışmasına imza attıkları görülmektedir. BIST 30 Endeksinde yer alan işletmelerin kurumsal sosyal sorumluluk faaliyetleri kapsamında ana kategorilerinin altında yer alan KSS uygulamalarıyla ilişkili olan alt kategorilere ne düzeyde yer verdikleri Tablo 6 içerisinde paylaşılmıştır.

Tablo 6. Kurumsal Sosyal Sorumluluk Alt Kategori Türlerinin Dağılımı (BIST 30) 


\begin{tabular}{|c|c|c|c|c|}
\hline \multicolumn{5}{|c|}{ BİST 30 Endeksi KSS Faaliyet Türleri } \\
\hline $\begin{array}{l}\text { Sosyal ve } \\
\text { Kültürel } \\
\text { Faaliyetler } \\
\end{array}$ & $\begin{array}{l}\text { Çevresel } \\
\text { Faaliyetler }\end{array}$ & $\begin{array}{l}\text { Eğitim } \\
\text { Odaklı } \\
\text { Faaliyetler }\end{array}$ & $\begin{array}{l}\text { Toplum } \\
\text { Sağlığı } \\
\text { Faaliyetleri }\end{array}$ & $\begin{array}{l}\text { Enerji } \\
\text { Verimliliği } \\
\text { Faaliyetleri }\end{array}$ \\
\hline (a1) $=\% 27$ & $(\mathrm{~b} 1)=\% 50$ & $(\mathrm{c} 1)=\% 18$ & $(\mathrm{~d} 1)=\% 44$ & $(\mathrm{e} 1)=\% 100$ \\
\hline$(\mathrm{a} 2)=\% 2$ & $(\mathrm{~b} 2)=\% 42$ & $(\mathrm{c} 2)=\% 0$ & $(\mathrm{~d} 2)=\% 56$ & $(\mathrm{e} 2)=\% 0$ \\
\hline (a3) $=\% 10$ & $(\mathrm{~b} 3)=\% 8$ & $(\mathrm{c} 3)=\% 6$ & & \\
\hline$(\mathrm{a} 4)=\% 14$ & $(\mathrm{~b} 4)=\% 0$ & $(\mathrm{c} 4)=\% 6$ & & \\
\hline$(\mathrm{a} 5)=\% 14$ & & $(\mathrm{c} 5)=\% 40$ & & \\
\hline$(\mathrm{a} 6)=\% 4$ & & $(\mathrm{c} 6)=\% 30$ & & \\
\hline \multicolumn{5}{|l|}{$(\mathrm{a} 7)=\% 12$} \\
\hline (a8) $=\% 17$ & & & & \\
\hline
\end{tabular}

BIST 30 Endeksinde yer alan ișletmelerin kurumsal sosyal sorumluluk açısından sosyal ve kültürel faaliyetler kapsamında ana kategorilerinin altında yer alan KSS uygulamalarıyla ilişkili olan alt kategorilerden en fazla (a1) görsel, işitsel ve dramatik sanatların gelişimi ve desteklenmesine yönelik faaliyetlere (\%27) yoğunlaştıkları görülmektedir. BİST 30 Endeksinde yer alan işletmelerin kurumsal sosyal sorumluluk açısından eğitim odaklı faaliyetler kapsamında ana kategorilerinin altında yer alan KSS uygulamalarıyla ilişkili olan alt kategorilerden en fazla (c5) diğer eğitim faaliyetlerine (\%40) yer verdikleri görülmektedir. BIST 30 Endeksinde yer alan işletmelerin kurumsal sosyal sorumluluk açısından çevresel faaliyetler kapsamında ana kategorilerinin altında yer alan KSS uygulamalarıyla ilişkili olan alt kategorilerden en fazla (b1) ağaçlandırma, fidan dikme ve orman geliştirme projelerine (\%50) yer verildiği görülmektedir. BIST 30 Endeksinde yer alan işletmelerin kurumsal sosyal sorumluluk açısından toplum sağlı̆̆ına yönelik faaliyetler kapsamında ana kategorilerinin altında yer alan KSS uygulamalarıyla ilişkili olan alt kategorilerden en fazla (d2) dezavantajlı grupların rehabilite edilmesine yönelik faaliyetlere (\%56) yoğunlaştıkları görülmektedir. BIST 30 Endeksinde yer alan işletmelerin kurumsal sosyal sorumluluk açısından enerji verimliliğine yönelik faaliyetler kapsamında ana kategorilerinin altında yer alan KSS uygulamalarıyla ilişkili olan alt kategorilerden en fazla enerji verimliliğini artırmaya yönelik faaliyetlere yer verdikleri tespit edilmiştir.

BİST 30, BİST 50 ve BİST 100 Endeksleri içinde yer alan işletmelerin yoğunlaştıkları KSS faaliyetleri açısından genel olarak belirgin bir farklılığın bulunmadığı görülmektedir. BİST 30, BİST 50 ve BİST 100 Endeksleri içinde yer alan işletmelerin kurumsal sosyal sorumluluk faaliyetleri içinde sosyal ve kültürel faaliyetlere sırasıyla $\% 42, \% 41$ ve $\% 36$ oranında yer verdikleri; çevresel faaliyetlere sırasıyla \%20, \%23 ve $\% 24$ oranında yer verdikleri; eğitim odaklı faaliyetlere sırasıyla $\% 27, \% 25$ ve $\% 27$ oranında yer verdikleri; toplum sağlığı faaliyetlerine sırasıyla $\% 8, \% 8$ ve $\% 10$ oranında yer verdikleri; enerji verimliliği faaliyetlerine $\% 3 \% 3$ ve $\% 3$ oranında yer verdikleri tespit edilmiștir. 
Grafik 4. BİST 30, BİST 50 ve BİST 100 Endeksleri KSS Faaliyet Yoğunlaşma Grafiği

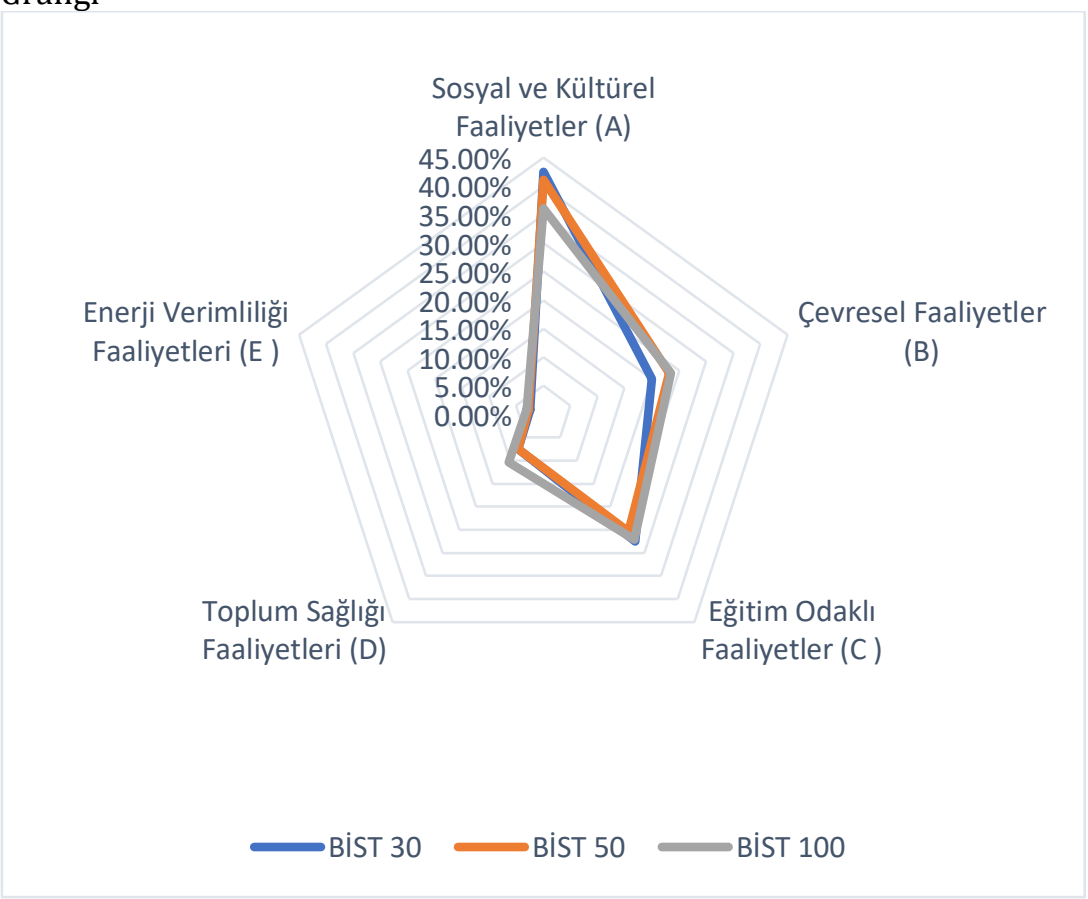

Grafik 4'te endekslerin yoğunlaştıkları KSS faaliyet türü odak ve alanlarının birbirleriyle benzerlik taşıdığı görülmektedir. Yoğunlaşılan KSS faaliyet türleri arasında anlamlı bir farklılık bulunmamaktadır. Bununla birlikte BİST 30, BİST 50 ve BİST 100 Endeksleri içinde yer alan işletmelerin, sosyal ve kültürel faaliyet türüne yönelik kurumsal sosyal sorumluluk ağırlıkları karşılaştırıldığında; BİST 100 Endeksi ağırlı̆ıının BIST 30 ve BIST 50 Endekslerine göre daha düşük olduğu görülmektedir. Yine toplum sağlığına yönelik kurumsal sosyal sorumluluk faaliyetlerinin Endeksler arasında benzer bir farklılı̆ı yansıttığı görülmektedir. BISST 100 Endeksi ağırlığının BISST 30 ve BİST 50 Endekslerine göre daha yüksek olduğu görülmektedir. Bu iki faaliyet türüne yönelik faaliyetlerde BİST 100 Endeksi faaliyet yoğunlaşmasının BİST 30 ve BİST 50 Endekslerine göre kısmen farklılık gösterdiği görülmektedir.

BIST 30, BİST 50 ve BİST 100 Endeksleri içinde yer alan ișletmelerin sektör açısından kurumsal sosyal sorumluluk faaliyet içeriği kapsamında hangi 
faaliyet türüne yoğunlaştıkları tema yoğunluğu açısından Tablo 7 içerisinde gösterilmiştir.

Tablo 7. BİST Endekslerinde Yer Alan İşletmelerin Sektör Açısından Yoğunlaștıkları KSS Faaliyet Türleri

\begin{tabular}{|c|c|c|c|}
\hline SEKTÖRLER & BİST 30 & BİST 50 & BİST 100 \\
\hline Finans & $\begin{array}{l}\text { Sosyal ve Kültürel } \\
\text { Faaliyetler }\end{array}$ & $\begin{array}{l}\text { Sosyal ve Kültürel } \\
\text { Faaliyetler }\end{array}$ & $\begin{array}{l}\text { Sosyal ve Kültürel } \\
\text { Faaliyetler }\end{array}$ \\
\hline Ana Metal Sanayi & $\begin{array}{l}\text { Sosyal ve Kültürel } \\
\text { Faaliyetler }\end{array}$ & $\begin{array}{l}\text { Sosyal ve Kültürel } \\
\text { Faaliyetler }\end{array}$ & $\begin{array}{l}\text { Sosyal ve Kültürel } \\
\text { Faaliyetler }\end{array}$ \\
\hline $\begin{array}{l}\text { Metal Eşya Makine ve } \\
\text { Ulaşım A. }\end{array}$ & $\begin{array}{l}\text { Sosyal ve Kültürel } \\
\text { Faaliyetler }\end{array}$ & $\begin{array}{l}\text { Sosyal ve Kültürel } \\
\text { Faaliyetler }\end{array}$ & $\begin{array}{l}\text { Sosyal ve Kültürel } \\
\text { Faaliyetler }\end{array}$ \\
\hline Holding Yatırım & $\begin{array}{l}\text { Sosyal ve Kültürel } \\
\text { Faaliyetler }\end{array}$ & $\begin{array}{l}\text { Sosyal ve Kültürel } \\
\text { Faaliyetler }\end{array}$ & $\begin{array}{l}\text { Sosyal ve Kültürel } \\
\text { Faaliyetler }\end{array}$ \\
\hline İmalat Sanayi & $\begin{array}{l}\text { Çevresel Faaliyetler, } \\
\text { Eğitim Odaklı } \\
\text { Faaliyetler }\end{array}$ & $\begin{array}{l}\text { Çevresel } \\
\text { Faaliyetler }\end{array}$ & $\begin{array}{l}\text { Çevresel } \\
\text { Faaliyetler }\end{array}$ \\
\hline $\begin{array}{l}\text { Kimya İlaç Petrol } \\
\text { Lastik ve Plastik }\end{array}$ & Çevresel Faaliyetler & $\begin{array}{l}\text { Sosyal ve Kültürel } \\
\text { Faaliyetler, } \\
\text { Eğitim Odaklı } \\
\text { Faaliyetler }\end{array}$ & $\begin{array}{l}\text { Sosyal ve Kültürel } \\
\text { Faaliyetler }\end{array}$ \\
\hline Enerji & & $\begin{array}{l}\text { Çevresel } \\
\text { Faaliyetler, Eğitim } \\
\text { Odaklı } \\
\text { Faaliyetler }\end{array}$ & $\begin{array}{l}\text { Eğitim Odaklı } \\
\text { Faaliyetler }\end{array}$ \\
\hline Gıda İçecek & & $\begin{array}{l}\text { Sosyal ve Kültürel } \\
\text { Faaliyetler }\end{array}$ & $\begin{array}{l}\text { Sosyal ve Kültürel } \\
\text { Faaliyetler }\end{array}$ \\
\hline $\begin{array}{l}\text { Teknoloji } \\
\text { (Bilișim/Savunma) }\end{array}$ & $\begin{array}{l}\text { Eğitim Odaklı } \\
\text { Faaliyetler } \\
\text { (Savunma) }\end{array}$ & $\begin{array}{l}\text { Sosyal ve Kültürel } \\
\text { Faaliyetler } \\
\text { (Savunma) }\end{array}$ & $\begin{array}{l}\text { Eğitim Odaklı } \\
\text { Faaliyetler } \\
\text { (Bilişim ve } \\
\text { Savunma) }\end{array}$ \\
\hline İnşaat Bayındırlık & & $\begin{array}{l}\text { Sosyal ve Kültürel } \\
\text { Faaliyetler, } \\
\text { Çevresel } \\
\text { Faaliyetler }\end{array}$ & $\begin{array}{l}\text { Sosyal ve Kültürel } \\
\text { Faaliyetler, } \\
\text { Çevresel } \\
\text { Faaliyetler }\end{array}$ \\
\hline Ticaret & & $\begin{array}{l}\text { Sosyal ve Kültürel } \\
\text { Faaliyetler, } \\
\text { Çevresel } \\
\text { Faaliyetler }\end{array}$ & $\begin{array}{l}\text { Sosyal ve Kültürel } \\
\text { Faaliyetler }\end{array}$ \\
\hline Ulaştırma & Çevresel Faaliyetler & $\begin{array}{l}\text { Çevresel } \\
\text { Faaliyetler }\end{array}$ & $\begin{array}{l}\text { Çevresel } \\
\text { Faaliyetler } \\
\end{array}$ \\
\hline Haberleşme & $\begin{array}{l}\text { Sosyal ve Kültürel } \\
\text { Faaliyetler }\end{array}$ & $\begin{array}{l}\text { Sosyal ve Kültürel } \\
\text { Faaliyetler, } \\
\text { Toplum Sağlığı } \\
\text { Faaliyetleri }\end{array}$ & $\begin{array}{l}\text { Sosyal ve Kültürel } \\
\text { Faaliyetler, } \\
\text { Toplum Sağlığı } \\
\text { Faaliyetleri }\end{array}$ \\
\hline
\end{tabular}

BİST 30, BİST 50 ve BİST 100 Endekslerinde yer alan sektör temsilcileri karşılaştırıldığında sosyal ve kültürel faaliyet türleri açısından 
farklılıkların bulunduğu görülmektedir. BİST 100 Endeksinde yer alan sektör temsilcilerinin BIST 50 Endeksi sektör temsilcilerine göre daha düşük yoğunlukta sosyal ve kültürel faaliyet türlerine yoğunlaştıkları tespit edilmiştir. BİST 50 Endeksinde yer alan sektör temsilcilerinin BİST 30 ve BİST 100 sektör temsilcilerine göre sosyal ve kültürel faaliyet türlerine daha fazla yoğunlaştıkları tespit edilmiştir.

BIST 30, BİST 50 ve BİST 100 Endekslerinde yer alan sektör temsilcileri karşılaştırıldığında çevresel faaliyet türleri açısından farklılıklar taşıdıkları tespit edilmiştir. BIST 30 ve BIST 100 Endeksinde yer alan sektör temsilcilerinin BIST 50 Endeksinde yer alan sektör temsilcilerine göre daha düşük yoğunlukta çevresel faaliyet türlerine yoğunlaştıkları tespit edilmiştir. BIST 30 ve BİST 100 Endeksinde yer alan sektör temsilcilerinin ise eșit düzeyde çevresel faaliyetlere yoğunlaştıkları gözlemlenmiştir. BIST 30, BIST 50 ve BİST 100 Endekslerinde yer alan; imalat sanayi ve ulaștırma sektör temsilcilerinin endeksler içerisinde herhangi bir farklılık taşımadıkları görülmektedir. İnşaat bayındırlık sektör temsilcilerinin sadece BISTT 50 ve BIST 100 Endekslerinde, kimya ilaç petrol lastik ve plastik ürünler sektör temsilcilerinin sadece BİST 30 Endeksinde, enerji ve ticaret sektör temsilcilerinin ise sadece BİST 50 Endeksi içerisinde çevresel faaliyet türlerine yoğunlaştıkları tespit edilmiştir.

BİST 30, BİST 50 ve BİST 100 Endekslerinde yer alan sektör temsilcileri karşılaştırıldığında eğitim odaklı faaliyet türleri açısından farklılıklar taşıdıkları tespit edilmiştir. Eğitim odaklı faaliyetlere endeksler içerisinde eşit düzeyde yer verilmiş olsa da sektör açısından farklılıklar bulunmaktadır. Teknoloji sektör temsilcilerinin BIST 30 ve BIST 100 Endeksi içerisinde eğitim odaklı faaliyetlere yoğunlaştıkları gözlemlenmiştir. Enerji sektör temsilcilerinin ise BİST 50 ve BİST 100 Endekslerinde eğitim odaklı faaliyetlere yer verdikleri gözlemlenmiştir. Kimya ilaç petrol lastik ve plastik ürünler sektör temsilcilerinin ise sadece BIST 50 Endeksinde, imalat sanayi sektör temsilcilerinin de sadece BISTT 30 Endeksinde eğitim odaklı faaliyetlere yoğunlaştıkları tespit edilmiştir.

BIST 30, BİST 50 ve BİST 100 Endekslerinde yer alan sektör temsilcileri karşıllaştırıldığında toplum sağlığına yönelik faaliyet türleri açısından farklılıklar taşıdıkları tespit edilmiştir. Toplum sağlığına yönelik faaliyet türlerine BİST 30 Endeksinde yer alan haberleşme sektör temsilcilerinin yer vermedikleri gözlemlenmiştir. Haberleşme sektör temsilcilerinin sadece BIST 50 ve BISST 100 Endeksi içerisinde toplum sağlığına yönelik faaliyet türlerine yoğunlaştıkları tespit edilmiştir.

\section{SONUÇ}

İşletmelerde kurumsal sosyal sorumluluk çalışmalarının etkisi doğrudan fark edilememesine rağmen müșteri ve çalışan bağlllığını artıran önemli bir çaba olarak kabul görmektedir. Kurumsal sosyal sorumluluk politikaları işletmelerin yeni pazarlara girişi ya da yeni stratejik işbirliklerine dahil olma sürecinde anahtar bir role sahiptir. Bağımsız ve ilişkisiz büyüme stratejilerinde işletmenin kurumsal sosyal sorumluluk yaklaşımı paydaş davranışlarını olumlu yönde etkileme potansiyeline sahiptir. Farklı düzeylerde 
aranan çevresel uyum, işletmenin kurumsal sosyal sorumluluk faaliyetleri ile daha sorunsuz ve kolay gerçekleşmektedir. Günümüzde işletmeler sadece ürettikleri ürün ve hizmet sunumu ile toplumun tüm beklentilerini karşılayamamaktadırlar. Toplum işletmelerden dolaylı olarak sosyal sorunlarına çözüm üretilmesi ve yaşam kalitesinin artırılmasını talep etmektedir. Dolayısı ile işletmelerin toplumsal sorunlara ve toplumsal refah seviyesi etki unsurlarına duyarlı olması beklenmektedir. Bu etkilerin farkında olan büyük işletmeler kurumsal sosyal sorumluluk çalışmalarını çok daha etkin ve sistematik biçimde uygulama çabası içindedir.

Çalıșma kapsamında BIST 100 içinde yer alan ișletmelerin kurumsal sosyal sorumluluk çalışmaları BIST 50 ve BİST 30 gibi daha özel endeksler ve sektör grupları açısından karşılaştırmalı bir analize tabi tutulmuştur. Kurumsal sosyal sorumluluk faaliyetleri kapsamında sosyal ve kültürel faaliyetler, çevresel faaliyetler, eğitim odaklı faaliyetler, toplum sağlığı faaliyetleri ve enerji verimliliği konuları çalışmanın ana kategorileri olarak belirlenmiştir. $\mathrm{Bu}$ ana kategorileri tanımlayan KSS uygulamalarıyla ilişkili olan alt temalar belirlenmiştir. BİST 100 içinde bulunan bütün işletmelerine bu temalar kapsamında ne tür kurumsal sosyal sorumluluk çalışması yaptığı kayıt altına alınarak alt tema ve ana kategori yoğunlukları belirlenmiștir.

BİST 100 Endeksi içerisinde yer alan işletmelerin KSS faaliyetleri genel olarak değerlendirildiğinde sosyal ve kültürel faaliyetlerin öncelikli tercih edilen çalışma alanı olduğu sonucuna ulaşılmıştır. Sosyal ve kültürel faaliyetlerden sonra sırasıyla eğitim odaklı faaliyetler, çevresel faaliyetler, toplum sağlığına yönelik faaliyetler ve enerji verimliliğine yönelik faaliyetlere yoğunlaşıldığı tespit edilmiștir. BİST 100 Endeksinde yer alan işletmeler sosyal ve kültürel faaliyet içeriklerinden en fazla görsel, işitsel ve dramatik sanatların gelişimi ve desteklenmesine yönelik faaliyetlere yer vermişlerdir. Sosyal ve kültürel faaliyet içeriklerinden ise en az bireylerin daha güvenli yaşam imkânlarına sahip olmalarına yönelik faaliyetlere yer verildiği tespit edilmiştir. Eğitim odaklı faaliyet içeriklerinden de işletmelerin en fazla diğer eğitim faaliyetlerine yoğunlaştıkları tespit edilmiştir. Diğer eğitim faaliyetleri içerisinde; üniversite, vakıf ve derneklerle yürütülen öğrencilerin yetkinliklerini arttırmaya yönelik faaliyetler, kariyer programları, okullara ekipman desteklerinin sağlanmasına yönelik faaliyetler yer almaktadır. Eğitim faaliyetleri kapsamında işletmelerin en az yoğunlaştıkları kurumsal sosyal sorumluluk faaliyet içeriğinin ise bilimsel çabaların desteklenmesine yönelik faaliyetler olduğu tespit edilmiștir. Çevresel faaliyetler kapsamında da en fazla doğa, çevre ve biyoçeşitliliğin korunmasına yönelik faaliyet içeriğine odaklanıldığı tespit edilmiştir. En az önem gösterilen çevresel faaliyetin ise karbon ayak izini azaltmaya yönelik çalışmalar olduğu tespit edilmiştir.

Çalışma sonucunda elde edilen verilerden BİST 100, BİST 50 ve BİST 30 Endekslerinde yer alan işletmeler belirlenen temalar açısından karş̧laştırıldığında yoğunlaşılan KSS faaliyetleri arasında fark bulunmadığı tespit edilmiştir. BIST 100, BIST 50 ve BIST 30 Endekslerinde yer alan işletmelerin kurumsal sosyal sorumluluk çalışmaları kapsamında en yoğun olarak sosyal ve kültürel faaliyetler temasına yönelik projeler ve faaliyetlerde bulundukları sonucuna ulaşılmıştır. Bu işletmelerin sosyal ve kültürel faaliyet 
içeriklerinden en yoğun olarak görsel işitsel ve dramatik sanatların gelişimi ve desteklenmesine yönelik faaliyetlere yer verdikleri gözlemlenmiştir. Endeks karşılaştırması sonucu yoğunlaşılan KSS faaliyet türleri arasında anlamlı bir farklılığın bulunmadığı tespit edilmiștir.

Çalışma sonucunda elde edilen verilerden endekslerde yer alan işletmeler sektör açısından karşılaştırıldığında, yoğunlaştıkları KSS faaliyetleri ve temaları arasında farklılıkların bulunduğu tespit edilmiştir. Sosyal ve kültürel faaliyet türleri açısından BíST 30 endeksinde yer alan sektör temsilcilerinin BIST 50 ve BİST 100 Endeksleri ile benzerlikler taşıdığı gözlemlenmiștir. Ancak, BIST 100 Endeksinde yer alan sektör temsilcilerinin BIST 50 Endeksi sektör temsilcilerine göre daha düșük yoğunlukta sosyal ve kültürel faaliyet türlerine yoğunlaştıkları tespit edilmiştir. BİST 50 Endeksinde yer alan sektör temsilcilerinin BİST 30 ve BíST 100 sektör temsilcilerine göre sosyal ve kültürel faaliyet türlerine daha fazla ilgi gösterdikleri sonucuna ulaşılmıştır. Çevresel faaliyet türleri açısından da BIST 30 ve BIST 100 Endeksinde yer alan sektör temsilcilerinin BISTT 50 Endeksinde yer alan sektör temsilcilerine göre daha düşük yoğunlukta çevresel faaliyet türlerine yoğunlaştıkları tespit edilmiştir. BIST 30 ve BISST 100 Endeksinde yer alan sektör temsilcilerinin ise eşit düzeyde çevresel faaliyetlere yoğunlaştıkları gözlemlenmiştir. Eğitim odaklı faaliyet türlerine ise endeksler içerisinde eşit düzeyde önem verildiği tespit edilmiştir.

İşletmeler, KSS faaliyetleriyle paydaşlarını etkilemekte ve paydaşlarından etkilenmektedir. Dolayısıyla işletmeler gerçekleştirdikleri faaliyetlerini ve faaliyet sonuçları hakkındaki bilgileri paydaşlarıyla paylaşmalıdır. Bu sonuçlar neticesinde, işletmelerin güncel olarak kurumsal sosyal sorumluluk faaliyetlerine kurumsal internet sitelerinde yer vermeleri ve sürdürülebilirlik raporları yayınlamaları işletme paydaşları açısından büyük öneme sahiptir. Nitel araștırma sürecinde elde edilen deneyim ve bulgulara göre BİST 100 endeksinde yer alan büyük ölçekli işletmelerin kurumsal sosyal sorumluluk faaliyetlerine yönelik standart ve objektif bir raporlama, değerlendirme ve kayıt sisteminin bulunmadığı, endeks içinde yer alan bazı ișletmelerin sürdürülebilirlik raporlarını düzenli aralıklarla yayınlamadıkları tespit edilmiştir. Bununla birlikte bu işletmelerin kurumsal internet sitelerinde ve sürdürülebilirlik raporlarında toplum sağlığı ve enerji verimliliği konusuna çokça atıfta bulundukları ancak bu faaliyet türlerine yönelik faaliyet somut sosyal sorumluluk projeleri gerçekleştirmedikleri görülmektedir.

BİST 30, BİST 50 ve BİST 100 Endeksinde faaliyet yürüten ișletmelerin 2018-2019 yılları arasındaki kurumsal internet sitelerinde KSS başlığı altında paylaştıkları uygulamalarının ve sürdürülebilirlik raporlarının karşılaştırmalı bir içerik analizine tabi tutulduğu bu çalışmadan yola çıkılarak farklı endeks ve temalar üzerine yeni çalışmalar yapılabilir. Bu çalışmada izlenen yol ve elde edilen sonuçların gelecekte yapılacak bilimsel çalışmalara, KSS disiplinine ve uygulayıcılara katkı sunması ümit edilmektedir. 


\section{KAYNAKÇA}

Akgeyik, T. (2007), “İnsan Kaynakları Yönetimi Boyutuyla Kurumsal Sosyal Sorumluluk: (Bir Alan Araştırması)", Sosyal Siyaset Konferansları Dergisi, (52), ss. 65-106.

Aktan, C. C. ve Börü, D. (2007), "Kurumsal Sosyal Sorumluluk: İşletmeler ve Sosyal Sorumluluk", (Ed.) C. C. Aktan, Kurumsal Sosyal Sorumluluk, İstanbul: İgiad Yayını.

Alkan, F. (2004). “İnsan Kaynakları Yönetiminde Sosyal Sorumluluk Uygulamaları ve Kurumsal Sosyal Sorumluluk ile İlişkisi”, Yüksek Lisans Tezi, İstanbul Üniversitesi Sosyal Bilimler Enstitüsü, İstanbul.

Aytar, O. (2019), "BíST Sürdürülebilirlik Endeksinde Yer Alan Şirketlerin Kurumsal Sosyal Sorumluluk Faaliyetleri Üzerine Bir İçerik Analizi", OPUS Uluslararası Toplum Araştırmaları Dergisi, 12, ss. 320340.

Awalluddin, M. A. (2020), "Shareholder Activism and Corporate Social Responsibility in Malaysia", Mehmet Akif Ersoy University Journal of Economics and Administrative Sciences Faculty, 7(1), ss. 1-19.

Bayraktaroğlu, G., İlter, B. ve Tanyeri, M. (2009). Kurumsal Sosyal Sorumluluk: Pazarlamada Yeni Bir Paradigmaya Doğru, İstanbul: Literatür Yayıncılık.

Ben-Amar, W., Francoeur, C., Marsat, S. ve Sijamic Wahid, A. (2021), "How Do Firms Achieve Corporate Social Performance? An İntegrated Perspective", Corporate Social Responsibility Environmental Management, ss. 1-13. https://doi.org/10.1002/csr.2107.

Chun, R. (2019), "How Virtuous Global Firms Say They Are: A Content Analysis of Ethical Values", Journal of Business Ethics, 155(1), ss. 5773.

Creswell, J. W. (2014), Research Design: Qualitative, Quantitative, and Mixed Methods Approaches, USA: Sage Publications.

Çalışkan, O. (2010). "Kurumsal Sosyal Sorumluluk Algılama Boyutunun Personelin İş Tatminine ve İşte Kalma Niyetine Etkisi: Antalya Bölgesinde Yer Alan Beş Yıldızlı Konaklama İşletmelerinde Çalışanlar Üzerinde Bir Araştırma", Doktora Tezi, Selçuk Üniversitesi Sosyal Bilimler Enstitüsü, Konya.

De Jong, M. D. T. ve Van Der Meer, M. (2017), “How Does It Fit? Exploring The Congruence Between Organizations and Their Corporate Social Responsibility (CSR) Activities", Journal of Business Ethics, 143(1), ss. 71-83.

Demirel, B. (2018), “Türkiye'nin İlk 200 İmalat Firmasının Periyodik Olarak Yayınlanan Kurumsal Sosyal Sorumluluk Raporlarının İçerik Analizi", Yüksek Lisans Tezi, Manisa Celal Bayar Üniversitesi Sosyal Bilimler Enstitüsü, Manisa.

Dusuki, A. W. ve Yusof, T. F. M. T. M. (2008), “The Pyramid of Corporate Social Responsibility Model: Empirical Evidence From Malaysian Stakeholder Perspectives", Malaysian Accounting Review, 7(2), ss. 29-54.

Ece, S. (2019), “Kobi Yöneticilerinin Kurumsal Sosyal Sorumluluklarının Karşılaştırılması: Şırnak ve Gaziantep Örneği", International Social Sciences Studies Journal, 5(41), ss. 4357-4363. 
Fidan, Z. ve Şentürk, Z. A. (2017), "Kurumsal Sosyal Sorumluluk (KSS) Çalışmalarında İşbirliği: Akbank, Garanti Bankası ve Türkiye İş Bankası Üzerine Bir Değerlendirme", Selçuk Üniversitesi İletişim Fakültesi Akademik Dergisi, 9(4), ss. 40-65.

Garriga, E. ve Mele, D. (2004), “Corporate Social Responsibility Theories: Mapping The Territory", Journal of Business Ethics, 53(1-2), ss. 5171.

Gümüş, M. ve Öksüz, B. (2009), “İtibar Sürecinde Kilit Rol: Kurumsal Sosyal Sorumluluk İletişimi", Journal of Yaşar University, 4(14), ss. 21292150.

Gürel, T. (2010), “Kurumsal Sosyal Sorumlulukta Yeni Yaklaşımlar ve Tartışılan Konular", Selçuk Üniversitesi İletişim Fakültesi Akademik Dergisi, 6(3), ss. 111-122.

Harris, H. (2001), “Content Analysis of Secondary Data: A Study of Courage in Managerial Decision Making", Journal of Business Ethics, 34(3-4), ss. 191-208.

Kelgökmen İlic, D. (2010), "İşletmelerin Kurumsal Sosyal Sorumluluk Düzeylerinin Belirlenmesine Yönelik Bir Literatür Taraması”, Ege Akademik Bakıș, 10(1), ss. 303-318.

Korkmaz, S. (2009), İşletmelerin Sosyal Sorumlulukları. Kocaeli: Umuttepe Yayınları.

Miniaoui, Z., Chibani, F. ve Hussainey, K. (2019), “The İmpact of Country-Level İnstitutional Differences On Corporate Social Responsibility Disclosure Engagement", Corporate Social Responsibility and Environmental Management, 26(2), ss. 1-13.

Özkan, A., Tanç, Ş. G. ve Taşdemir, B. (2018), “Sürdürülebilirlik Açıklamaları Kapsamında Kurumsal Sosyal Sorumluluğun Karlılık Üzerine Etkisi: BİST Sürdürülebilirlik Endeksinde Bir Araştırma", Muhasebe Bilim Dünyası Dergisi, 20(3), ss. 560-577.

Popping, R. (2000), Computer-Assisted Text Analysis. London: Sage Publications.

Pusak, S. (2014), “Türkiye'de Kurumsal Sosyal Sorumluluk Üzerine Bir Araştırma; Şirketlerin Periyodik Yayınlanan Kurumsal Sosyal Sorumluluk Raporlarının İçerik Analizi”, Yüksek Lisans Tezi, Çağ Üniversitesi Sosyal Bilimler Enstitüsü, Mersin.

Saran, M., Coşkun, G., Zorel, F. İ. ve Aksoy, Z. (2011), “Üniversitelerde Sosyal Sorumluluk Bilincinin Gelisstirilmesi: Ege Üniversitesi Topluma Hizmet Uygulamaları Dersi Üzerine Bir Araștırma", Journal of Yaşar University, 6(22), ss. 3732-3747.

Sarıkaya, M. ve Akarca, Y. (2011), "Kurumsal Sosyal Sorumlulukta Ölçüm Teknikleri", Denetişim, (8), ss. 60-67.

Soysal, B. (2019). "Kurumsal Sosyal Sorumluluk İletişiminde Kurumsal Sosyal Sorumluluk Raporlamasının Etkinliği: Türkiye'deki Şirketler Üzerine Bir Araştırma", Yüksek Lisans Tezi, İstanbul Ticaret Üniversitesi Sosyal Bilimler Enstitüsü, İstanbul.

Süklüm, N. ve Hiçyorulmaz, E. (2019), "BíST Sürdürülebilirlik Endeksindeki İşletmelerin Sosyal Sorumluluk ve Çevre Muhasebesi İlişkisi Açısından İncelenmesi: Bir İçerik Analizi", Business \& Management Studies: An International Journal, 7(4), ss. 1806-1824. 
Şahin, U. (2019), “Kurumsal Sosyal Sorumluluk Perspektifinden Marka Algısı Yaratılması ve Sosyal Medya Kullanımı Üzerine Bir Araştırma", Yüksek Lisans Tezi, Marmara Üniversitesi Sosyal Bilimler Enstitüsü, İstanbul.

Şahinolanlar, F. (2015), “Sosyal Sorumluluk Uygulamalarından Sponsorluk Faaliyetlerinin Paydaşlarca Algılanması ve Bir Uygulama", Yüksek Lisans Tezi, İstanbul Gelişim Üniversitesi Sosyal Bilimler Enstitüsü, İstanbul.

Tarcan İçigen, E., Çevik, B. ve Doğan, O. (2016), “Türkiye'de Faaliyet Gösteren Uluslararası Konaklama İşletmelerinin Sosyal Sorumluluk Uygulamalarının İncelenmesi", Mediterranean Journal of Humanities, 6(2), ss. 299-310.

Yalman, Y. (2018), “Türkiye'de Kurumsal Sosyal Sorumluluk Uygulamalarının İșletmelerin Kurumsal İtibarına Etkileri: İșletme Yöneticilerinin Algıları Üzerine Bir Araştırma", Doktora Tezi, Afyon Kocatepe Üniversitesi Sosyal Bilimler Enstitüsü, Afyonkarahisar.

Yıldırım, A. (2013), "Kurumsal Sosyal Sorumluluk Açıklamalarının Finansal Performans Üzerine Etkisi: BİST-30'da Bir Uygulama", Yüksek Lisans Tezi, Balıkesir Üniversitesi Sosyal Bilimler Enstitüsü, Balıkesir. 